\title{
IMPACTS OF ALTERNATE FURROW IRRIGATION AND N- FERTILIZATION LEVEL ON PERFORMANCE OF ONION UNDER MIDDLE EGYPT CONDITIONS
}

\author{
M. M. Ewis and M. I. Badawi \\ Soil, Water \& Environment Research Institute, Agricultural Research Center, Giza, Egypt.
}

Received: Jun. 25, 2016

Accepted: Jul. 20,2016

ABSTRACT: Two field experiments were conducted in 2012/2013 and 2013/2014 winter seasons at Sids Agric. Res. Station, Beni-Suef, Egypt to find out the extent to which onion crop performance was affected by alternate furrow irrigation technique. Two alternate furrow irrigation regimes were assessed i.e. irrigating at 14 or 28 days intervals, comparing with the common furrow irrigation regime. These irrigation regimes were combined with 60, 90 and 120 $\mathrm{kgNfed}^{-1}$ levels and tested in a split plot design with four replicates, where irrigation regimes were represented in the main plots, whereas split ones were assigned for $N$ levels. Onion yield and quality, applied water as well as water, $N$ and consumptive use efficiencies were considered. The most important results could be summarized as follows:

1- The marketable onion bulb and total yields were significantly increased under Alternate Furrow Irrigation at 14 days interval $\left(A F I_{14}\right)$, comparable with Alternate Furrow Irrigation at 28 days interval $\left(A F I_{28}\right)$ and common furrow irrigation (EFI). The highest values of bulb weight, bulb diameter, bulb total soluble solids (TSS \%) and bulb dry matter (DM \%) were obtained with $\mathrm{AFI}_{14}$ regime. Increasing $\mathrm{N}$ level resulted in gradual increases in marketable, total, culls onion bulb yields, onion bulb weight, bulb diameter, bulb TSS and DM\%. The interaction of $A F I_{14}$ regime and $120 \mathrm{~kg} \mathrm{Nfed}^{1}$ level resulted in the highest figures of the abovementioned parameters.

2- The highest values of seasonal applied water were under every-furrow irrigation (EFI) and reached to 2247 and $2209 \mathrm{~m}^{3} \mathrm{fed}^{-1}$, which reduced by (24.86 and 7.29\%) and by (24.52 and 7.22\%) under $\mathrm{AFI}_{28}$ and $\mathrm{AFI}_{14}$ regimes, respectively, in the consecutive two seasons. The highest seasonal $\mathrm{Cu}$ (1712.28 and $1642.37 \mathrm{~m}^{3} \mathrm{fed}^{-1}$ ) were recorded under EFI, which tended to reduction under $\mathrm{AFI}_{28}$ and $\mathrm{AFI}_{14}$ regimes with 17.98 and $5.71 \%$ in $1^{\text {st }}$ season, and 19.83 and $6.63 \%$ in $2^{\text {nd }}$ season, respectively, lower than that with EFI regime. Increasing $\mathrm{N}$ level resulted in gradual increased $\mathrm{Cu}$ values, and interaction of EFI regime and $120 \mathrm{~kg} \mathrm{Nfed}^{1}$ level revealed the highest $\mathrm{Cu}$ value.

3- The $\mathrm{AFI}_{14}$ regime exhibited the highest values of Irrigation Water Productivity, Water and $\mathrm{N}$ Use Efficiencies, whereas Consumptive Use Efficiency was improved with $\mathrm{AFI}_{28}$ regime. Irrigation Water Productivity, Water and Consumptive Use Efficiencies, were increased gradually with increasing $N$ level, whereas $N$ use efficiency exhibited a differed trend.

On conclusion, $A \mathrm{FI}_{14}$ regime is capable to mitigate the water stress, during the irrigation cycle, and to increase onion bulb yield. In addition, it is obviously noticed that the alternate furrow irrigation at 14-days interval and120 $\mathrm{kgNfed}^{-1}$ is the best combination to achieve higher marketable onion bulb yield and to improve irrigation and $N$ use efficiencies as well.

Key words: Onion crop, alternate furrow irrigation, $N$ fertilization level, water and consumptive use efficiencies, $\mathrm{N}$-use efficiency

\section{INTRODUCTION}

The available water resources in Egypt are limited which restrict the horizontal crop production in the newly reclaimed areas.
Agriculture is heavily relied on irrigation and consumes more than $84 \%$ of available water resources (El-Beltagy and Abo-Hadeed, 2008). Furrow irrigation is the common 
scheme in conveying the water to the row cultivated crops. Under such irrigation scheme inevitable over irrigation is expected, particularly, in the upper part of the field near the water inlet causing lower water application efficiency. The deeply percolated water resulting in leaching pesticides and other harmful chemicals out the root zone causing an acute environmental pollution in particular for shallow ground water which frequently used for drinking in the most Egyptian rural areas. So, optimizing irrigation water is an important and beneficial issue in saving water, fertilizers and in general sustaining the agricultural sector.

Onion (Allium cepa L.) is an important vegetable crop in Egypt for exportation and local consumption. Onion is a shallowrooted plant that requires frequent irrigation to achieve the yield potential. Accordingly, with furrow irrigation on keeping proper soil moisture in the root zone, irrigation must be applied frequently, so, higher amounts of water is generally applied to the crop. Sammis et al. (2000) stated that onion is regarded a fairly large water consumer and water deficiency decrease in its evapotranspiration and consequently yield. Towards achieving the yield potential, the proper inputs for onion production, in particular, water and $\mathrm{N}$ fertilizer must be considered. In this respect, Kassam et al. (2007) reported that improving the management of agricultural water is the basic need to conserve water, energy and soil while satisfying society's increasing demand for food and fiber.

Alternate furrow irrigation (AFI) is powerful tool to reduce both water applied and irrigation costs and produce acceptable crop yield and water productivity as well. In Egypt, EL- Sharkawy et al. (2006) stated that AFI is a way to save irrigation water, improve irrigation efficiency, and increase onion yield. With maize crop, Zhang et al. (2000) found that AFI uses less irrigation water but can maintain the same maize grain yield production as that of conventional furrow irrigation with high irrigation amounts. Furthermore, Awad (2013) reported that Irrigation water saving in the $\mathrm{AFI}_{7}$ and $\mathrm{AFI}_{14}$ was approximately $7 \%$ and $17 \%$, respectively, and improved both maize crop water use efficiency and irrigation water productivity as compared with EFI. In addition, Okasha et al. (2013) with maize, stated that alternative furrows irrigation gave the highest values of irrigation water use efficiency (IWUE) and decreased amount of applied water irrigation by $35 \%$, comparable with continuous flow irrigation.

All crops require nitrogen $(\mathrm{N})$ for the production of a photosynthetically active canopy, whose functionality will strongly influence the crop performance. The supplied nitrogen to the plant will influence the amount of protein, protoplasm and chlorophyll formed. In turn, this influences cell size and leaf area, photosynthetic activity and consequently the final economic yield. Although greater $\mathrm{N}$ application has produced higher yields, this is not a linear relationship and there is an economic optimum application offsetting incremental yield increase against the cost of additional $\mathrm{N}$ inputs, which needs to be determined for individual cultivars (King et al. 2003). Nitrogen is an essential element for both crop growth and productivity. The beneficial effect of nitrogen application on onion yield was previously reported, where Moursy et al. (2007) found that application of $190.4 \mathrm{~kg}$ $\mathrm{N} /$ ha rate gave significantly increased in onion yield, bulb diameter and TSS content as compared with $95.2 \mathrm{~kg} \mathrm{Nha}^{-1}$ one. In addition, Yaso et al. (2007) revealed that increasing mineral nitrogen levels led to significant increases on average bulb weight, marketable and total bulbs yield, and total soluble solid of onion. Moreover, Awad et al. (2011) found that application of $\mathrm{N}$ at 62, 124 , and $248 \mathrm{~kg} \mathrm{ha}^{-1}$ rates increased onion yield, as compared to those of the plants that received no N. In general, because of shallow and unbranched root system, onion and other alliums are most 
susceptible compared to many crops in extracting moisture and nutrients (Kebede, 2003), thus water and $\mathrm{N}$ management a key factor in its production.

The objectives of the present research study are to investigate the effects of two alternate furrow irrigation regimes, comparable with traditional regime as combined with three different nitrogen levels and their interaction as well on onion yield, quality, irrigation water productivity and consumptive use efficiency in order to find out the most proper combination resulting in higher onion and water productivity under Beni Sueif Government circumstances, Middle Egypt area.

\section{MATERIALS AND METHODS}

This investigation was conducted at Sids Agricultural Research Station, Bani-Suef Governorate, Middle Egypt during 2012/2013 and 2013/2014 winter seasons to study the effect of three irrigation schemes and three nitrogen fertilization levels and their interaction on onion bulb yield and some quality traits besides some crop water relations. The onion cultivar Giza 6 Mohassan (Allium cepa L.) was used in this study. Some hydrological and chemical soil properties and particle size distribution as well were determined according to Klute (1986) and Page et al. (1982). Data are presented in Tables 1 and 2. A split plot design with four replicates was used. The main plots were devoted to water placement regimes, while the sub plots were assigned to the nitrogen fertilization levels as shown below.

\section{1- Main- plots (water placement regimes)}

Every-furrow irrigation (Traditional furrow irrigation at 28 days interval, EFI

Alternate-furrow irrigation at 28 days interval, $\mathrm{AFI}_{28}$.

Alternate-furrow irrigation at 14 days interval, $\mathrm{AFI}_{14}$.

Table 1: Bulk density and some soil - water constants for the experimental site in 2012/2013 and 2013/2014 seasons.

\begin{tabular}{|c|c|c|c|c|c|}
\hline Season & $\begin{array}{l}\text { Depth } \\
\text { (cm) }\end{array}$ & $\begin{array}{l}\text { Field capacity } \\
\qquad(\%, w t / w t)\end{array}$ & $\begin{array}{l}\text { Wilting point } \\
\text { (\%, wt/wt) }\end{array}$ & $\begin{array}{c}\text { Available water } \\
(\%, \mathbf{w t} / \mathbf{w t})\end{array}$ & $\begin{array}{l}\text { Bulk density } \\
\left(\mathrm{gcm}^{-3}\right)\end{array}$ \\
\hline \multirow{4}{*}{$2012 / 2013$} & $00-15$ & 46.56 & 22.17 & 24.39 & 1.17 \\
\hline & $15-30$ & 37.09 & 17.66 & 19.43 & 1.29 \\
\hline & $30-45$ & 35.55 & 16.92 & 18.63 & 1.36 \\
\hline & $45-60$ & 33.19 & 15.80 & 17.39 & 1.38 \\
\hline \multicolumn{2}{|l|}{ Mean } & 38.10 & 18.14 & 19.96 & 1.29 \\
\hline \multirow{4}{*}{$2013 / 2014$} & $00-15$ & 45.08 & 21.58 & 23.50 & 1.13 \\
\hline & $15-30$ & 37.95 & 18.04 & 19.91 & 1.24 \\
\hline & $30-45$ & 35.95 & 17.32 & 18.63 & 1.28 \\
\hline & $45-60$ & 33.14 & 16.04 & 17.10 & 1.33 \\
\hline \multicolumn{2}{|l|}{ Mean } & 38.03 & 18.25 & 19.88 & 1.25 \\
\hline
\end{tabular}


Table 2: Particle size distribution and some chemical properties of the experimental soil at 2012/2013 and 2012/2013.

\begin{tabular}{|c|c|c|c|c|c|c|c|c|c|c|}
\hline \multirow{3}{*}{ Season } & \multicolumn{3}{|c|}{$\begin{array}{l}\text { Particle size } \\
\text { distribution }\end{array}$} & & \multicolumn{6}{|c|}{ Chemical properties } \\
\hline & \multirow{2}{*}{$\begin{array}{c}\text { Clay } \\
\%\end{array}$} & \multirow{2}{*}{$\begin{array}{l}\text { Silt } \\
\%\end{array}$} & \multirow{2}{*}{$\begin{array}{c}\text { Sand } \\
\%\end{array}$} & \multirow[t]{2}{*}{ class } & \multirow{2}{*}{$\begin{array}{l}\text { OM } \\
\%\end{array}$} & \multirow{2}{*}{$\begin{array}{l}\mathrm{E}_{\mathrm{C}}, \mathrm{dSm}^{-1} \\
\text { (at } 25^{\circ} \mathrm{C} \text { ) }\end{array}$} & \multicolumn{3}{|c|}{ Available (ppm) } & \multirow[t]{2}{*}{ pH } \\
\hline & & & & & & & $\mathbf{N}$ & $\mathbf{P}$ & K & \\
\hline $2012 / 2013$ & 49.90 & 33.80 & 16.30 & Clayey & 1.20 & 0.53 & 45.0 & 12.5 & 202.5 & 7.9 \\
\hline $2013 / 2014$ & 50.20 & 33.45 & 16.35 & Clayey & 1.57 & 0.66 & 37.0 & 11.0 & 203.8 & 7.8 \\
\hline
\end{tabular}

2- Sub-plots (nitrogen fertilization levels)

$$
\begin{array}{ll}
\mathrm{N}_{1}-60 \mathrm{~kg} \mathrm{Nfed}^{-1} & \mathrm{~N}_{2}-90 \mathrm{~kg} \mathrm{Nfed}^{-1} \\
\mathrm{~N}_{3}-120 \mathrm{~kg} \mathrm{Nfed}^{-1} &
\end{array}
$$

The area of each sub-plot was $42 \mathrm{~m}^{2}$ $(1 / 100$ fed) i.e. $6 \mathrm{~m}$ width (10 ridges $\times 0.60$ $\mathrm{m}$ apart) $\times 7 \mathrm{~m}$ length. Seedlings were planted on 5-7 cm apart on both sides of ridge. Onion seeds were sown in the nursery on $5^{\text {th }}$ and $15^{\text {th }}$ September, and the seedlings were transplanted on $15^{\text {th }}$ and $20^{\text {th }}$ November in 2012/2013 and 2013/2014 seasons, respectively. The recommended doses of calcium super phosphate $(15.5 \%$ $\left.\mathrm{P}_{2} \mathrm{O}_{5}\right)$ and potassium sulphate $\left(48 \% \quad \mathrm{~K}_{2} \mathrm{O}\right)$ were applied during land preparation. The preceding crops were soybean and maize in 2012/2013 and 2013/2014 seasons, respectively. The adopted $\mathrm{N}$ levels were added at two equal doses as ammonium nitrate $(33.5 \% \mathrm{~N})$. The first dose was applied after thirty days from transplanting and the second was applied one month later. Irrigation events and applied water under the adopted irrigation schemes are presented in Table 3. Irrigation water was conveyed to the plots through a circular orifice and its quantity was calculated using the equation described by (Michael, (1978) as follows:

Where:

$$
\mathrm{Q}=\mathrm{CA} \sqrt{2 \mathrm{gh}}
$$

$Q=$ water discharged through the orifice, $\mathrm{cm}^{3} \mathrm{sec}^{-1}$.

$\mathrm{C}=$ coefficient of discharge ranged from 0.6 up to 0.8 .
$A=$ cross-sectional area of the orifice, $\mathrm{cm}^{2}$.

$\mathrm{g}=$ acceleration of gravity, $981 \mathrm{cmsec}^{-2}$.

$\mathrm{h}=$ pressure head causing discharge through the orifice, $\mathrm{cm}$.

At harvest, averages of bulb weight $(\mathrm{g})$, bulb diameter $(\mathrm{cm})$, marketable, culls (double + bolter) and total yields $\left(\right.$ tfed $\left.^{-1}\right)$, total soluble solids percentage (TSS\%) and of dry matter percentage (DM\%) in bulbs were determined according to AOAC, 1975.

\section{Statistical analysis:}

All collected data were subjected to statistical analysis as described by Snedecor and Cochran (1980). The means were compared using least significant difference (LSD) at $5 \%$ probability level.

\section{Consumptive use $(\mathrm{Cu})$ :}

Consumptive use $(\mathrm{Cu})$ or so called crop evapotranspiration (Etc) was determined based on soil moisture depletion (S.M.D.) in the effective root zone as outlined by Hansen, et al. (1979):

$$
\mathrm{Cu}=\frac{\mathrm{Q}_{2} \mathrm{Q}_{1}}{-\mathrm{-a0}} \times \mathrm{Bd} \times \mathrm{d}
$$

Where:

$\mathrm{Cu}=$ actual water consumptive use in $\mathrm{cm}$.

$\mathrm{Q}_{2}=$ soil moisture content after 48 hours from irrigation (\%,wt/wt).

$\mathrm{Q}_{1}=$ soil moisture content before irrigation (\%, wt/wt).

$\mathrm{Bd}=$ bulk density of the specified soil layer $\left(\mathrm{gcm}^{-3}\right)$.

$d=$ depth of soil layer $(60 \mathrm{~cm})$. 
Table 3: Number of irrigation and applied water $\left(\mathrm{m}^{3} \mathrm{fed}{ }^{-1}\right)$ for each irrigation under different irrigation treatments during the $2012 / 2013$ and 2013/2014 seasons.

\begin{tabular}{|l|c|c|c|c|c|c|}
\hline \multirow{2}{*}{ Irrigation event } & \multicolumn{3}{|c|}{ EFI } & \multicolumn{2}{c|}{$\mathrm{AFI}_{28}$} & \multicolumn{2}{c|}{$\mathrm{AFI}_{14}$} \\
\cline { 2 - 7 } & $\mathbf{2 0 1 2 / 2 0 1 3}$ & $\mathbf{2 0 1 3 / 2 0 1 4}$ & $\mathbf{2 0 1 2 / 2 0 1 3}$ & $\mathbf{2 0 1 3 / 2 0 1 4}$ & $\mathbf{2 0 1 2 / 2 0 1 3}$ & $\mathbf{2 0 1 3 / 2 0 1 4}$ \\
\hline Transplanting & 562.8 & 537.6 & 562.8 & 537.6 & 562.8 & 537.6 \\
Second & 252.0 & 285.6 & 252.0 & 285.6 & 252.0 & 285.6 \\
Third & 373.8 & 365.4 & 243.6 & 256.2 & 176.4 & 168.0 \\
Fourth & 365.4 & 357.0 & 226.8 & 239.4 & 172.2 & 163.8 \\
Fifth & 361.2 & 344.4 & 210.0 & 201.6 & 168.0 & 160.0 \\
Sixth & 331.8 & 319.2 & 193.2 & 147.0 & 159.6 & 159.2 \\
Seventh & --- & --- & --- & --- & 155.4 & 155.4 \\
Eighth & --- & --- & --- & --- & 151.2 & 147.0 \\
Ninth & --- & --- & --- & --- & 147.0 & 138.6 \\
Tenth & --- & --- & --- & --- & 138.6 & 134.4 \\
\hline Total (m ${ }^{3}$ /fed) & 2247.0 & 2209.2 & 1688.4 & 1667.4 & 2083.2 & 2049.6 \\
\hline
\end{tabular}

EFI: Every-furrow irrigation; $\mathrm{AFI}_{28}$ and $\mathrm{AFI}_{14}$ are alternate furrow irrigation with 28 and 14 days intervals, respectively

\section{Irrigation Water Productivity (IWP)}

Water productivity is an efficiency term calculated as a ratio of product output over water input. The output could be biological goods such as crop grain, fodder, bulbs ....etc. So, water productivity, in the present study, is expressed as kilograms of onion bulbs obtained per the unit of applied irrigation water as follows:

IWP $\left(\mathrm{kgm}^{-3}\right)=$ Total bulb yield $\left(\mathrm{kgfed}^{-1}\right) /$ Water applied $\left(\mathrm{m}^{3} \mathrm{fed}^{-1}\right)$, Ali et al. (2007)

Water Use Efficiency (WUE, $\mathrm{Kgm}^{-3}$ ): Water use efficiency was estimated according to Jensen (1983) as follows:

Where:

$$
W U E=\frac{Y}{C U}
$$

WUE $=\mathrm{kgm}^{-3}$

$\mathrm{Y}=$ Total bulb yield $\left(\mathrm{kgfed}^{-1}\right)$

$\mathrm{CU}=$ Seasonal water consumptive use $\left(\mathrm{m}^{3} \mathrm{fed}^{-1}\right)$
Nitrogen Use Efficiency (NUE): Nitrogen Use Efficiency was computed as onion bulb yield $\left(\mathrm{kgfed}^{-1}\right.$ ) and $\mathrm{N}$ applied $\left(\mathrm{kgfed}^{-1}\right)$ ratio was estimated as below:

NUE $=$ Marketable bulb yield $\left(\mathrm{kgfed}^{-1}\right) /$ $\mathrm{N}$ applied $\left(\mathrm{kgfed}^{-1}\right)$

Consumptive use efficiency (Ecu, \%):

The consumptive use efficiency (Ecu) was estimated according to Doornbos and Pruit (1975) as follows:

$$
\begin{aligned}
\text { Ecu } \%= & \text { Water consumptive use }\left(\mathrm{m}^{3} \mathrm{fed}-1\right) \mathrm{X} \\
& 100 / \text { Water applied }\left(\mathrm{m}^{3} \mathrm{fed}^{-1}\right)
\end{aligned}
$$

\section{RESULTS AND DISCUSSION \\ Total, Marketable and Culls onion yields $\left(\right.$ tfed $\left.^{-1}\right)$ :}

Onion and other alliums crops are characterized with shallow and unbranched root system, so, they are most susceptible compared to many crops in extracting soil moisture and nutrients (Kebede, 2003) so, water and $\mathrm{N}$ management a key factor in its production. Data in Table 4 indicated that 
the adopted irrigation schemes and/or $\mathrm{N}$ fertilization levels significantly influenced marketable, culls and total onion yields in the two seasons of study.

Concerning irrigation schemes, $\mathrm{AFI}_{14}$ resulted in the highest total onion yield reached 17.19 and 14.92 tonfed $^{-1}$, respectively, in $1^{\text {st }}$ and $2^{\text {nd }}$ seasons. The values tended to reduction under EFI and $\mathrm{AFI}_{28}$ regimes and comprised 7.74 and $13.85 \%$ in $1^{\text {st }}$ season and 8.45 and $14.81 \%$ in $2^{\text {nd }}$ season, lower than those with $\mathrm{AFI}_{14}$ regime. Respecting marketable bulb yield, similar trend was observed, where the highest figures e.g.15.09 and 13.55 tonfed ${ }^{1}$ were recorded with $\mathrm{AFI}_{14}$ regime, respectively, in $1^{\text {st }}$ and $2^{\text {nd }}$ seasons. Under $\mathrm{EFI}$ and $\mathrm{AFI}_{28}$ regimes the values tended to reduction and amounted to 9.94 and $18.03 \%$ in $1^{\text {st }}$ season and to 9.96 and $18.08 \%$ in $2^{\text {nd }}$ season, lesser than those with $\mathrm{AFI}_{14}$ regime. Data in Table 4 illustrated that culls onion yield exhibited differed trend as influenced by the adopted irrigation schemes. Higher values of culls onion yields were attained with $\mathrm{EFI}$ and $\mathrm{AFI}_{28}$ regimes, which reached to 2.28 and 2.45 tonfed $^{-1}$ in $1^{\text {st }}$ season and to 1.54 and 1.60 tonfed $^{-1}$ in $2^{\text {nd }}$ season, respectively. Culls onion yield under $\mathrm{AFI}_{14}$ regime was decreased by 7.90 and $14.29 \%$ in $1^{\text {st }}$ season and by 11.04 and $23.89 \%$ in $2^{\text {nd }}$ season, respectively, lower than those with $\mathrm{EFI}$ and $\mathrm{AFI}_{28}$ regimes. El- Sharkawy et al. (2006) reported that modified AFI regime (irrigating at 15 days interval) surpassed both $\mathrm{EFI}$ and $\mathrm{AFI}$ regimes (both irrigating at 30 days interval) to produce higher onion bulbs yield. Furthermore, Abdel-Maksoud et al. (2002) and Awad (2013) with maize crop, found that modified AFI (irrigating at 7 days interval) resulted in higher grain yield, comparable with $\mathrm{EFI}$ and $\mathrm{AFI}$ those irrigating at 14 days interval.

The substantial decreases in total and marketable yields under $\mathrm{AFI}_{28}$ regime, comparing with $\mathrm{EFI}$ regime, may be due to less applied irrigation water, which did not match full onion water requirements, caused water stress, and consequently reduced crop yield. Under $\mathrm{AFI}_{14}$ regime higher values of total and marketable yields, compared with $\mathrm{EFI}$ and $\mathrm{AFI}_{28}$ regimes, proved that irrigation timing is a detrimental factor, in water management, and so efficient water use. In addition, with $\mathrm{AFI}_{14}$ regime the soil moisture may be more available during the entire irrigation cycle, which enhanced water and nutrient uptake and doubtless reflected on final total and marketable onion yields.

As for the effects of the adopted nitrogen fertilization levels on onion bulb yields, data in Table 4 reveal that increasing $\mathrm{N}$ level resulted in gradual increases in total, marketable and culls onion bulb yields, and such findings were true in the two seasons. The increases in total and marketable yields due to $120 \mathrm{~kg} \mathrm{Nfed}^{-1}$ level were $(6.87$ and $26.86 \%)$ and (6.93 and $28.66 \%)$ in $1^{\text {st }}$ season and were (11.92 and $29.51 \%)$ and $(12.97$ and $31.75 \%)$ in $2^{\text {nd }}$ season, respectively, higher than those with 90 and $60 \mathrm{~kg} \mathrm{Nfed}^{-1}$ levels The culls bulb yield exhibited similar trend, where the highest figures e.g. 2.44 and $1.64 \mathrm{tfed}^{-1}$, respectively, were recorded in $1^{\text {st }}$ and $2^{\text {nd }}$ seasons. Under 90 and $60 \mathrm{~kg} \mathrm{Nfed}^{-1}$ levels the values tended to reduce and amounted to 6.15 and $14.34 \%$ in $1^{\text {st }}$ season and to 8.54 and $17.07 \%$ in $2^{\text {nd }}$ season, respectively, comparable with $120 \mathrm{~kg} \mathrm{Nfed}^{-1}$ level. The present findings are confirming the fact that all crops (including onion) require nitrogen $(\mathrm{N})$ for the production of a photosynthetically active canopy, whose functionality will strongly influence the crop performance Moursy et al. (2007) found that application of $190.4 \mathrm{~kg} \mathrm{~N} / \mathrm{ha}$ rate gave significantly increasing onion yield, bulb diameter and TSS content as compared with $95.2 \mathrm{~kg} \mathrm{~N} / \mathrm{ha}$ one. In addition, Yaso et al. (2007) revealed that increasing mineral nitrogen levels led to significant increases on average bulb weight, marketable and total bulbs yield as well as total soluble solid of onion. In connection, Awad et al. (2011) found that application of $\mathrm{N}$ at 62,124 , and $248 \mathrm{~kg}$ ha-1 rates gradually increased onion yield, as 
compared to those of the plants that received no N. Furthermore, Aliyu et al. (2007) and Kemal et al. (2013) reported that total yield of onion and shallot (Allium cepa var. ascalonicum Baker), respectively, was gradually increased as $\mathrm{N}$ rate increased.
The interaction of $\mathrm{AFI}_{14}$ regime and 120 $\mathrm{kg} \mathrm{Nfed}^{-1}$ level resulted in the highest total and marketable bulb yields in the two seasons of study. On the contrary the lowest values were attained due to $\mathrm{AFI}_{28}$ regime as interacted with $60 \mathrm{kgNfed}^{-1}$ level in the two seasons of study.

Table 4: Marketable, culls and total yields $\left(\mathrm{tfed}^{-1}\right)$ as affected by irrigation schemes and $\mathrm{N}$ levels in 2012/2013 and 2013/2014 seasons.

\begin{tabular}{|c|c|c|c|c|c|c|c|}
\hline \multirow{3}{*}{$\begin{array}{c}\text { Irrigation } \\
\text { scheme } \\
\text { (I) }\end{array}$} & \multirow{3}{*}{$\begin{array}{c}\text { Nitrogen levels } \\
\text { (N) }\end{array}$} & \multicolumn{3}{|c|}{$2012 / 2013$} & \multicolumn{3}{|c|}{ 2013/2014 } \\
\hline & & Marketable & Culls & Total & Marketable & Culls & Total \\
\hline & & \multicolumn{3}{|c|}{$\left(\mathrm{tfed}^{-1}\right)$} & \multicolumn{3}{|c|}{$\left(\right.$ tfed $\left.^{-1}\right)$} \\
\hline \multirow{3}{*}{ EFI } & $60 \mathrm{~kg} \mathrm{Nfed}^{-1}$ & 11.20 & 2.08 & 13.29 & 10.05 & 1.36 & 11.41 \\
\hline & $90 \mathrm{~kg} \mathrm{Nfed}^{-1}$ & 14.19 & 2.37 & 16.56 & 12.39 & 1.57 & 13.96 \\
\hline & $120 \mathrm{~kg} \mathrm{Nfed}^{-1}$ & 15.37 & 2.38 & 17.75 & 14.15 & 1.68 & 15.58 \\
\hline \multicolumn{2}{|l|}{ Mean } & 13.59 & 2.28 & 15.86 & 12.20 & 1.54 & 13.66 \\
\hline \multirow{3}{*}{$\mathrm{AFI}_{28}$} & $60 \mathrm{~kg} \mathrm{Nfed}^{-1}$ & 10.56 & 2.32 & 12.88 & 9.52 & 1.51 & 11.03 \\
\hline & $90 \mathrm{~kg} \mathrm{Nfed}^{-1}$ & 12.87 & 2.38 & 15.25 & 11.22 & 1.56 & 12.78 \\
\hline & $120 \mathrm{~kg} \mathrm{Nfed}^{-1}$ & 13.67 & 2.64 & 16.31 & 12.59 & 1.73 & 14.32 \\
\hline \multicolumn{2}{|l|}{ Mean } & 12.37 & 2.45 & 14.81 & 11.11 & 1.60 & 12.71 \\
\hline \multirow{3}{*}{$\mathrm{AFI}_{14}$} & $60 \mathrm{~kg} \mathrm{Nfed}^{-1}$ & 13.52 & 1.88 & 15.40 & 12.18 & 1.22 & 13.40 \\
\hline & 90 kg Nfed $^{-1}$ & 15.39 & 2.12 & 17.51 & 13.40 & 1.38 & 14.79 \\
\hline & $120 \mathrm{~kg} \mathrm{Nfed}^{-1}$ & 16.36 & 2.30 & 18.66 & 15.07 & 1.51 & 16.57 \\
\hline \multicolumn{2}{|l|}{ Mean } & 15.09 & 2.10 & 17.19 & 13.55 & 1.37 & 14.92 \\
\hline \multicolumn{8}{|c|}{$\mathrm{N}$ levels mean } \\
\hline \multicolumn{2}{|l|}{$60 \mathrm{~kg} \mathrm{Nfed}^{-1}$} & 11.76 & 2.09 & 13.85 & 10.58 & 1.36 & 11.96 \\
\hline \multicolumn{2}{|c|}{$90 \mathrm{~kg} \mathrm{Nfed}^{-1}$} & 14.15 & 2.29 & 16.44 & 12.34 & 1.50 & 13.84 \\
\hline \multicolumn{2}{|c|}{$120 \mathrm{~kg} \mathrm{Nfed}^{-1}$} & 15.13 & 2.44 & 17.57 & 13.94 & 1.64 & 15.49 \\
\hline \multirow{3}{*}{ LSD, 0.05} & (I) & 0.53 & 0.30 & 0.61 & 0.68 & 0.30 & 0.59 \\
\hline & (N) & 0.45 & 0.25 & 0.52 & 0.40 & 0.15 & 0.45 \\
\hline & I X N & 0.77 & 0.44 & 0.90 & 0.69 & 0.27 & 0.78 \\
\hline
\end{tabular}




\section{Bulb weight and bulb diameter}

The onion yield components e.g. bulb weight and bulb diameter were affected significantly with the adopted irrigation schemes and/or $\mathrm{N}$ fertilization levels in the two seasons of study, Table 5. As for the influence of irrigation schemes, $\mathrm{AFI}_{14}$ regime exhibited the highest figures of onion bulb weight and bulb diameter, which amounted to $97.7(\mathrm{~g})$ and $5.86(\mathrm{~cm})$ in $1^{\text {st }}$ season and $87.83 \mathrm{~g}$ and $5.71 \mathrm{~cm}$ in $2^{\text {nd }}$ season, respectively. Under $\mathrm{EFI}$ and $\mathrm{AFI}_{28}$ regimes, lower values for bulb weight were recorded and comprised 19.99 and $28.45 \%$ in $1^{\text {st }}$ season and 19.86 and $28.37 \%$ in $2^{\text {nd }}$ season, respectively, lower than those with $\mathrm{AFI}_{14}$ regime. Bulb diameter trait showed similar trend, where the corresponding reduction values, under $\mathrm{EFI}$ and $\mathrm{AFI}_{28}$ regimes, reached to 8.36 and $15.02 \%$ in $1^{\text {st }}$ season and 8.23 and $15.41 \%$ in $2^{\text {nd }}$ season, comparable with $\mathrm{AFI}_{14}$ regime. The obtained results indicated that onion crop performance was improved under $\mathrm{AFI}_{14}$ regime, and the crop was capable to use the water and $\mathrm{N}$ inputs efficiently. El- Sharkawy et al. (2006) reported a different, where EFI insignificantly surpassed both modified AFI regime (irrigating at 15 days interval) and AFI regimes (irrigating at 30 days interval) to produce higher onion bulbs weight and bulb diameter traits, and such trend could be attributed to varietal differences and soil and prevailing weather conditions. Ayas and Demirtas (2009) found that bulb diameter and bulb weight were increased with the applied irrigation water. Kemal (2013) reported that bulb diameter tended to reduction due to $50 \%$ ETc level, comparable with 100 and $120 \%$ ETc levels.

Table 5: Bulb weight $(\mathrm{g})$ and bulb diameter $(\mathrm{cm})$ as affected by irrigation treatments and nitrogen levels in 2012/2013 and 2013/2014 seasons.

\begin{tabular}{|c|c|c|c|c|c|}
\hline \multirow{2}{*}{$\begin{array}{l}\text { Irrigation } \\
\text { schemes } \\
\text { (I) }\end{array}$} & \multirow{2}{*}{$\begin{array}{c}\text { Nitrogen levels } \\
\text { (N) }\end{array}$} & \multicolumn{2}{|c|}{ 2012/2013 } & \multicolumn{2}{|c|}{$2013 / 2014$} \\
\hline & & $\begin{array}{l}\text { Bulb weight } \\
\text { (g) }\end{array}$ & $\begin{array}{l}\text { Bulb diameter } \\
\text { (cm) }\end{array}$ & $\begin{array}{l}\text { Bulb weight } \\
\text { (g) }\end{array}$ & $\begin{array}{l}\text { Bulb diameter } \\
\text { (cm) }\end{array}$ \\
\hline \multirow{3}{*}{ EFI } & $60 \mathrm{~kg} \mathrm{Nfed}^{-1}$ & 60.44 & 4.98 & 54.46 & 4.85 \\
\hline & $90 \mathrm{~kg} \mathrm{Nfed}^{-1}$ & 75.65 & 5.36 & 65.89 & 5.22 \\
\hline & $120 \mathrm{~kg} \mathrm{Nfed}^{-1}$ & 98.61 & 5.79 & 90.82 & 5.64 \\
\hline \multicolumn{2}{|l|}{ Mean } & 78.23 & 5.37 & 70.39 & 5.24 \\
\hline \multirow{3}{*}{$\mathrm{AFI}_{28}$} & 60 kg Nfed $^{-1}$ & 53.55 & 4.44 & 48.24 & 4.33 \\
\hline & $90 \mathrm{~kg} \mathrm{Nfed}^{-1}$ & 69.37 & 5.16 & 60.42 & 5.04 \\
\hline & $120 \mathrm{~kg} \mathrm{Nfed}^{-1}$ & 86.95 & 5.34 & 80.08 & 5.12 \\
\hline \multicolumn{2}{|l|}{ Mean } & 69.95 & 4.98 & 62.91 & 4.83 \\
\hline \multirow{3}{*}{$\mathrm{AFI}_{14}$} & $60 \mathrm{~kg} \mathrm{Nfed}^{-1}$ & 90.29 & 5.40 & 81.35 & 5.27 \\
\hline & $90 \mathrm{~kg} \mathrm{Nfed}^{-1}$ & 96.65 & 5.99 & 84.19 & 5.83 \\
\hline & $120 \mathrm{~kg} \mathrm{Nfed}^{-1}$ & 106.36 & 6.19 & 97.96 & 6.04 \\
\hline \multicolumn{2}{|l|}{ Mean } & 97.77 & 5.86 & 87.83 & 5.71 \\
\hline \multicolumn{6}{|c|}{$\mathrm{N}$ levels mean } \\
\hline \multirow{3}{*}{\multicolumn{2}{|c|}{$\begin{array}{l}60 \mathrm{~kg} \mathrm{Nfed}^{-1} \\
90 \mathrm{~kg} \mathrm{Nfed}^{-1} \\
120 \mathrm{~kg} \mathrm{Nfed}^{-1}\end{array}$}} & 68.09 & 4.94 & 61.35 & 4.82 \\
\hline & & 80.56 & 5.50 & 70.16 & 5.36 \\
\hline & & 97.31 & 5.77 & 89.62 & 5.60 \\
\hline \multirow{3}{*}{ LSD, 05} & (I) & 8.51 & 0.33 & 7.54 & 0.32 \\
\hline & $(\mathrm{N})$ & 2.81 & 0.20 & 2.27 & 0.20 \\
\hline & IXN & 4.87 & 0.35 & 3.92 & 0.34 \\
\hline
\end{tabular}


Concerning effects of the adopted $\mathrm{N}$ levels, $120 \mathrm{~kg} \mathrm{Nfed}^{-1}$ level exhibited the highest figures of onion bulb weight and bulb diameter which amounted to $97.31(\mathrm{~g})$ and $5.77(\mathrm{~cm})$ in $1^{\text {st }}$ season, and $89.62(\mathrm{~g})$ and $5.60(\mathrm{~cm})$ in $2^{\text {nd }}$ season, respectively. The bulb weight seemed to decrease under 90 and $60 \mathrm{~kg} \mathrm{Nfed}^{-1}$ levels by 17.21 and $30.03 \%$ in $1^{\text {st }}$ season, and by 21.71 and $31.54 \%$ in $2^{\text {nd }}$ season, respectively, comparable with120 kg Nfed ${ }^{-1}$ level. The bulb diameter trait exhibited similar trend, where the reduction under 90 and $60 \mathrm{~kg}$ $\mathrm{Nfed}^{-1}$ levels amounted to 4.68 and $14.38 \%$ in $1^{\text {st }}$ season, and to 4.29 and $13.93 \%$ in $2^{\text {nd }}$ season, respectively, comparing with $120 \mathrm{~kg}$ $\mathrm{Nfed}^{-1}$ level.

In this sense, Aliyu et al. (2007) stated that mean of onion blub weight and bulb diameter were gradually increased due to increasing $\mathrm{N}$ level. In addition, Kemal (2013) found that bulb number and average bulb diameter were increased due to increasing $\mathrm{N}$ level. Gessesew et al. (2015) reported that increasing $\mathrm{N}$ fertilizer increased the mean weight of onion bulbs.

The interaction data indicated that $\mathrm{AFI}_{14}$ regime as interacted with120 kg Nfed ${ }^{-1}$ level exhibited higher onion bulb weight and bulb diameter, and such trend was true in the two seasons of study, Table 5 .

\section{Total soluble solids (TSS \%) and dry matter (DM \%):}

Total soluble solids (TSS \%) and dry matter (DM \%) of onion bulbs were significantly influenced due to the adopted irrigation schemes and/or $\mathrm{N}$ fertilization levels in the two seasons of study, Table 6 . As for the tested irrigation schemes, $\mathrm{AFI}_{14}$ regime resulted in the highest values of TSS and $\mathrm{DM} \%$, which amounted to 14.99 and $14.74 \%$ in $1^{\text {st }}$ season, and 14.62 and $14.25 \%$ in $2^{\text {nd }}$ season, respectively. The values of $\mathrm{TSS} \%$ under $\mathrm{EFI}$ and $\mathrm{AFI}_{28}$ regimes were decreased by 7.81 and $4.87 \%$, comparing with $\mathrm{AFI}_{14}$. El- Sharkawy et al. (2006) reported that modified AFI regime (irrigating at 15 days interval) surpassed both EFI and AFI regimes (both irrigating at 30 days interval) to produce higher TSS and DM \% values for onion bulbs.

Concerning TSS and DM\% for onion blub as affected by $\mathrm{N}$ fertilization levels, data revealed that the highest figures were recorded under $120 \mathrm{~kg} \mathrm{Nfed}^{-1}$ level and reached to 14.78 and $14.52 \%$ in $1^{\text {st }}$ season, and by 14.41 and $14.03 \% \%$ in $2^{\text {nd }}$ season, respectively. Under 90 and $60 \mathrm{~kg} \mathrm{Nfed}^{-1}$ levels, TSS \% seemed to reduce by 1.22 and $7.37 \%$ in $1^{\text {st }}$ season, and by 3.40 and $7.29 \% \%$ in $2^{\text {nd }}$ season, respectively, compared with120 kg Nfed ${ }^{-1}$ level.

The values of DM\% followed a similar trend, where DM\% was reduced by 3.65 and $6.40 \%$ in $1^{\text {st }}$ season, and by 3.64 and $6.34 \%$ in $2^{\text {nd }}$ season, respectively, under 90 and 60 $\mathrm{kg} \mathrm{Nfed}^{-1}$ levels comparing with120 $\mathrm{kg} \mathrm{Nfed}^{-1}$ level. In this sense, Yaso and Abdel Razzak (2007) reported that TSS\% and bulb weight of onion bulb were insignificantly increased due to increasing $\mathrm{N}$ rate to 90 or $120 \mathrm{~kg} \mathrm{Nfed}^{-1}$ levels, comparable with 60 one.

The interaction data indicated that $\mathrm{AFI}_{14}$ regime as interacted with $120 \mathrm{~kg} \mathrm{Nfed}^{-1}$ level exhibited higher TSS and DM\% figures, and such trend was true in the two seasons of study.

\section{Applied Irrigation Water (AIW, m $^{3}$ fed $\left.^{-1}\right)$ :}

Data in Table 3 show the amounts of applied irrigation water in each irrigation and seasonally as well. The highest values of seasonally water applied were recorded under every-furrow irrigation (EFI) and reached to 2247 and $2209 \mathrm{~m}^{3} \mathrm{fed}^{-1}$ in $2012 / 2013$ and 2013/2014, respectively. The values were reduced by ( 24.86 and $7.29 \%$ ) and by (24.52 and $7.22 \%$ ) under $\mathrm{AFI}_{28}$ and $\mathrm{AFI}_{14}$ regimes, respectively, in 2012/2013 and 2013/2014. It is well known that onion uses most of its water requirement from the 
top foot of soil due to its shallow root system. Thus, moisture needs per application are small and some deep percolation is inevitable. With onion crop irrigation, water must be controlled in order to minimize the water losses via deep percolation. The present findings indicated the potency of $\mathrm{AFI}$ in reducing the quantity of applied water. In this sense, El- Sharkawy et al. (2006) in 2 - season trial, found that applied water for onion crop under AFI and modified AFI regimes were lower by (29.30 $30.57 \%$ ) and (8.23 and $9.47 \%)$, respectively, compared with EFI regime. Furthermore, Zhang et al. (2000), Awad (2013) and Okasha et al. (2013) with maize crop recorded a similar trend.

\section{Seasonal consumptive use (CU, $\mathrm{m}^{3} \mathrm{fed}^{-1}$ ):}

The crop consumptive use is affected by natural factors such as prevailing weather and soil type and topography. In addition, the management factors including water supply and quality, crop variety, fertilization level, irrigation practice... etc are also affecting consumptive use. Results in Table 7 reveal that, seasonal $\mathrm{CU}$ for onion was clearly differed due to the adopted irrigation schemes, and the highest values i.e. 1712.28 and $1642.37 \mathrm{~m}^{3} \mathrm{fed}^{-1}$ were recorded under EFI in 2012/2013 and 2013/2014 seasons, respectively. The $\mathrm{Cu}$ values tended to reduction under $\mathrm{AFI}_{28}$ and $\mathrm{AFI}_{14}$ regimes, where the reduction amounted to 17.98 and $5.71 \%$ in $1^{\text {st }}$ season, and 19.83 and $6.63 \%$ in $2^{\text {nd }}$ season, respectively, comparable with EFI regime. Such reduction in $\mathrm{CU}$ with $\mathrm{AFI}_{28}$ and $\mathrm{AFI}_{14}$ regimes is attributable to lower applied water and soil moisture content that subjected to canopy transpiration and surface soil evaporation, which directly responsible for lower $\mathrm{CU}$ values. In connection, Ibrahim and Emara (2010) and Awad (2013) with sugar beet and corn crops, respectively, reported that water applied throughout traditional furrow irrigation was higher than that applied via AFI regime.

Table 6: Total soluble solids (TSS \%) and dry mater (DM \%) as affected by irrigation treatments and nitrogen levels in 2012/2013 and 2013/2014 seasons.

\begin{tabular}{|c|c|c|c|c|c|}
\hline \multirow{2}{*}{$\begin{array}{c}\text { Irrigation } \\
\text { schemes } \\
\text { (I) }\end{array}$} & \multirow{2}{*}{$\begin{array}{c}\text { Nitrogen levels } \\
\text { (N) }\end{array}$} & \multicolumn{2}{|c|}{$2012 / 2013$} & \multicolumn{2}{|c|}{$2013 / 2014$} \\
\hline & & $\begin{array}{c}\text { T.S.S. } \\
(\%)\end{array}$ & $\begin{array}{l}\text { D.M. } \\
(\%)\end{array}$ & $\begin{array}{c}\text { T.S.S. } \\
(\%)\end{array}$ & $\begin{array}{l}\text { D.M. } \\
(\%)\end{array}$ \\
\hline EFI & $\begin{array}{l}60 \mathrm{~kg} \mathrm{Nfed}^{-1} \\
90 \mathrm{~kg} \mathrm{Nfed}^{-1} \\
120 \mathrm{~kg} \mathrm{Nfed}^{-1}\end{array}$ & $\begin{array}{l}13.03 \\
14.40 \\
14.04\end{array}$ & $\begin{array}{l}12.75 \\
13.18 \\
13.73\end{array}$ & $\begin{array}{l}12.72 \\
13.07 \\
13.70\end{array}$ & $\begin{array}{l}12.33 \\
12.74 \\
13.24\end{array}$ \\
\hline Mean & & 13.82 & 13.22 & 13.16 & 12.77 \\
\hline $\mathrm{AFI}_{28}$ & $\begin{array}{l}60 \mathrm{~kg} \mathrm{Nfed}^{-1} \\
90 \mathrm{~kg} \mathrm{Nfed}^{-1} \\
120 \mathrm{~kg} \mathrm{Nfed}^{-1}\end{array}$ & $\begin{array}{l}13.52 \\
14.43 \\
14.82\end{array}$ & $\begin{array}{l}13.71 \\
14.03 \\
14.68\end{array}$ & $\begin{array}{l}13.18 \\
14.07 \\
14.46\end{array}$ & $\begin{array}{l}13.27 \\
13.56 \\
14.20\end{array}$ \\
\hline Mean & & 14.26 & 14.14 & 13.90 & 13.67 \\
\hline $\mathrm{AFI}_{14}$ & $\begin{array}{l}60 \mathrm{~kg} \mathrm{Nfed}^{-1} \\
90 \mathrm{~kg} \mathrm{Nfed}^{-1} \\
120 \mathrm{~kg} \mathrm{Nfed}^{-1}\end{array}$ & $\begin{array}{l}14.53 \\
14.98 \\
15.47\end{array}$ & $\begin{array}{l}14.29 \\
14.76 \\
15.16\end{array}$ & $\begin{array}{l}14.17 \\
14.61 \\
15.09\end{array}$ & $\begin{array}{l}13.82 \\
14.27 \\
14.66\end{array}$ \\
\hline Mean & & 14.99 & 14.74 & 14.62 & 14.25 \\
\hline \begin{tabular}{|l}
$N$ levels me \\
60 kg Nfed \\
90 kg Nfed \\
120 kg Nfec
\end{tabular} & & $\begin{array}{l}13.69 \\
14.60 \\
14.78 \\
\end{array}$ & $\begin{array}{l}13.59 \\
13.99 \\
14.52 \\
\end{array}$ & $\begin{array}{l}13.36 \\
13.92 \\
14.41 \\
\end{array}$ & $\begin{array}{l}13.14 \\
13.52 \\
14.03 \\
\end{array}$ \\
\hline Interaction & & & & & \\
\hline LSD, 05 & $\begin{array}{l}(I) \\
(N) \\
I X N\end{array}$ & $\begin{array}{l}0.45 \\
0.24 \\
0.42\end{array}$ & $\begin{array}{l}0.51 \\
0.24 \\
0.41\end{array}$ & $\begin{array}{l}0.44 \\
0.23 \\
0.41\end{array}$ & $\begin{array}{l}0.49 \\
0.23 \\
0.40\end{array}$ \\
\hline
\end{tabular}


As for $\mathrm{Cu}$ of onion as affected by the adopted $\mathrm{N}$ fertilization rates, data in Table 7 reveal a gradual increase in $\mathrm{Cu}$ as $\mathrm{N}$ level increased, and the highest values e.g. 1709.90 and $1649.32 \mathrm{~m}^{3} \mathrm{fed}^{-1}$ were attained with $120 \mathrm{~kg} \mathrm{Nfed}^{-1}$ level, respectively, in $2012 / 2013$ and 2013/2014 seasons. The higher CU values under $120 \mathrm{~kg} \mathrm{Nfed}^{-1}$ level reached to 7.36 and $16.45 \%$ in $1^{\text {st }}$ season and 9.78 and $23.02 \%$ higher than those with 90 and $60 \mathrm{~kg} \mathrm{Nfed}^{-1}$ levels, respectively. Such increase in seasonal evapotranspiration following nitrogen application may be attributable to the enhancing effect of $\mathrm{N}$-fertilizer on onion growth which consequently extracted more soil moisture which reflected on higher seasonal water use. In this sense, Kemal (2013) reported that Shallot plant height and number of leaves and $\mathrm{CU}$ as well were increased due to increasing $\mathrm{N}$ rate, and an increase in $\mathrm{N}$ by $1 \mathrm{~kg} \mathrm{ha}^{-1}$ can increase the marketable and total bulb yields by 0.022 and $0.0158 \mathrm{t} \mathrm{ha}^{-1}$.

Interaction effect of $\mathrm{EFI}$ regime and 120 $\mathrm{kg} \mathrm{Nfed}^{-1}$ level exhibited the highest $\mathrm{CU}$ values, and those findings were true in 2012/2013 and 2013/2014 seasons. On the contrary, $\mathrm{AFI}_{28}$ regime as interacted with 60 $\mathrm{kg} \mathrm{Nfed}^{-1}$ resulted in the lowest CU values, in the two seasons of study.

Table 7: Water consumptive use (m3fed-1) as affected by irrigation schemes and nitrogen levels in 2012/2013 and 2013/2014 seasons.

\begin{tabular}{|c|c|c|c|c|}
\hline \multirow{2}{*}{$\begin{array}{c}\text { Irrigation } \\
\text { schemes } \\
\text { (I) }\end{array}$} & \multirow{2}{*}{$\begin{array}{l}\text { Nitrogen } \\
\text { levels } \\
\text { (N) }\end{array}$} & \multicolumn{3}{|c|}{ Water consumptive use $\left(m^{3} f_{e d}^{-1}\right)$} \\
\hline & & 2012/2013 & 2013/20134 & Mean \\
\hline \multirow{3}{*}{ EFI } & $60 \mathrm{~kg} \mathrm{Nfed}^{-1}$ & 1565.32 & 1475.45 & 1520.39 \\
\hline & $90 \mathrm{~kg} \mathrm{Nfed}^{-1}$ & 1712.26 & 1656.31 & 1684.29 \\
\hline & $120 \mathrm{~kg} \mathrm{Nfed}^{-1}$ & 1859.25 & 1795.35 & 1827.30 \\
\hline \multicolumn{2}{|l|}{ Mean } & 1712.28 & 1642.37 & 1677.32 \\
\hline \multirow{3}{*}{$\mathrm{AFI}_{28}$} & $60 \mathrm{~kg} \mathrm{Nfed}^{-1}$ & 1297.89 & 1155.83 & 1226.86 \\
\hline & $90 \mathrm{~kg} \mathrm{Nfed}^{-1}$ & 1410.70 & 1325.70 & 1368.20 \\
\hline & $120 \mathrm{~kg} \mathrm{Nfed}^{-1}$ & 1504.85 & 1468.32 & 1486.59 \\
\hline \multicolumn{2}{|l|}{ Mean } & 1404.48 & 1316.62 & 1360.55 \\
\hline \multirow{3}{*}{$\mathrm{AFI}_{14}$} & $60 \mathrm{~kg} \mathrm{Nfed}^{-1}$ & $1422 . .76$ & 1390.80 & 1406.78 \\
\hline & 90 kg Nfed $^{-1}$ & 1655.25 & 1525.25 & 1590.25 \\
\hline & $120 \mathrm{~kg} \mathrm{Nfed}^{-1}$ & 1765.60 & 1684.28 & 1724.94 \\
\hline \multicolumn{2}{|l|}{ Mean } & 1614.54 & 1533.44 & 1573.99 \\
\hline \multicolumn{5}{|c|}{$\mathrm{N}$ levels mean } \\
\hline \multicolumn{2}{|c|}{$60 \mathrm{~kg} \mathrm{Nfed}^{-1}$} & 1428.66 & 1340.69 & 1384.68 \\
\hline \multicolumn{2}{|c|}{$90 \mathrm{~kg} \mathrm{Nfed}^{-1}$} & 1592.74 & 1502.42 & 1547.58 \\
\hline \multicolumn{2}{|c|}{$120 \mathrm{~kg} \mathrm{Nfed}^{-1}$} & 1709.90 & 1649.32 & 1679.61 \\
\hline
\end{tabular}


Irrigation Water productivity (IWP, $\mathrm{kgm}^{-3}$ ) and Water Use Efficiency (WUE, $\mathbf{~ k g m}^{-3}$ ):

Data in Table 8 cleared that less applied irrigation water under $\mathrm{AFI}_{28}$ regime resulted in higher IWP values comprised 24.22 and $23.30 \%$ more than with EFI regime, respectively, in 2012/2013 and 2013/2014 seasons. Similar trends were noticed with $\mathrm{AFI}_{14}$ regime, however, the increases in IWP were less and amounted to 16.86 and $17.80 \%$, in $2012 / 2013$ and $2013 / 2014$ seasons respectively, comparable with EFI regime. Regarding WUE for onion crop as influenced by the adopted irrigation regimes, $\mathrm{AFI}_{14}$ regime enhanced WUE values by 15.37 and $1.31 \%$ in $1^{\text {st }}$ season and by 17.25 and $0.83 \%$ in $2^{\text {nd }}$ season as compared with $\mathrm{EFI}$ and $\mathrm{AFI}_{28}$ irrigation regimes, respectively. These findings confirmed that $\mathrm{AFI}_{14}$ regime is advantageous compared with $\mathrm{AFI}_{28}$ regime because of improving IWP and WUE via reducing both the applied irrigation water and $\mathrm{CU}$ values with increasing onion bulb yield, whereas improving IWP and WUE due to $\mathrm{AFI}_{28}$ is attributed to lower applied water and $\mathrm{CU}$ values, which accompanied with reduced bulb yield. El- Sharkawy et al. (2006) stated that (AFI) improved crop water utilization efficiency for onion crop. Similar trends were recorded by Abdel-Maksoud et al. (2002) with maize crop.

Table 8: Irrigation Water Productivity, Water Use Efficiency, N Use Efficiency and Consumptive Use Efficiency as affected by irrigation schemes and/or nitrogen levels in 2012/2013 and 2013/2014 seasons.

\begin{tabular}{|c|c|c|c|c|c|c|c|c|c|}
\hline \multirow{2}{*}{$\begin{array}{c}\text { Irrigation } \\
\text { schemes } \\
\text { (I) }\end{array}$} & \multirow{2}{*}{$\begin{array}{c}\text { Nitrogen } \\
\text { level }\end{array}$} & \multicolumn{4}{|c|}{ 2012/2013 } & \multicolumn{4}{|c|}{ 2013/2014 } \\
\hline & & $\begin{array}{c}\text { IWP } \\
\left(\mathrm{kgm}^{-3}\right)\end{array}$ & $\begin{array}{c}\text { WUE } \\
\left(\mathrm{kgm}^{-3}\right)\end{array}$ & $\begin{array}{l}\text { Ecu } \\
(\%)\end{array}$ & $\begin{array}{c}\text { NUE } \\
\left(\mathrm{kgkgN}^{-1)}\right.\end{array}$ & $\begin{array}{c}\text { IWP } \\
\left(\mathrm{kgm}^{-3}\right)\end{array}$ & $\begin{array}{c}\text { WUE } \\
\left(\mathrm{kgm}^{-3}\right)\end{array}$ & $\begin{array}{l}\text { Ecu } \\
(\%)\end{array}$ & $\begin{array}{c}\text { NUE } \\
\left(\mathrm{kgkgN}^{-1)}\right.\end{array}$ \\
\hline \multirow{3}{*}{ EFI } & $60 \mathrm{kgNfed}^{-1}$ & 5.91 & 8.49 & 69.66 & 186.67 & 5.18 & 7.76 & 66.79 & 167.50 \\
\hline & $90 \mathrm{kgNfed}^{-1}$ & 7.37 & 9.67 & 76.20 & 157.67 & 6.32 & 8.43 & 74.97 & 137.67 \\
\hline & $120 \mathrm{kgNfed}^{-1}$ & 7.90 & 9.55 & 82.74 & 128.08 & 7.05 & 8.68 & 81.27 & 117.92 \\
\hline \multicolumn{2}{|l|}{ Mean } & 7.06 & 9.24 & 72.87 & 157.47 & 6.18 & 8.29 & 74.34 & 141.03 \\
\hline \multirow{3}{*}{$\mathrm{AFI}_{28}$} & $60 \mathrm{kgNfed}^{-1}$ & 7.63 & 9.92 & 76.87 & 176.00 & 6.62 & 9.54 & 69.32 & 158.67 \\
\hline & $90 \mathrm{kgNfed}^{-1}$ & 9.03 & 10.81 & 83.55 & 143.00 & 7.66 & 9.64 & 79.51 & 124.67 \\
\hline & $120 \mathrm{kgNfed}^{-1}$ & 9.66 & 10.84 & 89.13 & 113.92 & 8.59 & 9.75 & 88.06 & 104.92 \\
\hline \multicolumn{2}{|l|}{ Mean } & 8.77 & 10.52 & 83.18 & 144.31 & 7.62 & 9.64 & 78.96 & 129.42 \\
\hline \multirow{3}{*}{$\mathrm{AFI}_{14}$} & $60 \mathrm{kgNfed}^{-1}$ & 7.39 & 10.82 & 68.30 & 225.33 & 6.53 & 9.63 & 67.86 & 203.00 \\
\hline & $90 \mathrm{kgNfed}^{-1}$ & 8.41 & 10.58 & 79.46 & 171.00 & 7.22 & 9.70 & 74.42 & 148.89 \\
\hline & $120 \mathrm{kgNfed}^{-1}$ & 8.96 & 10.57 & 84.75 & 136.33 & 8.08 & 9.84 & 82.18 & 125.58 \\
\hline \multicolumn{2}{|l|}{ Mean } & 8.25 & 10.66 & 77.50 & 177.55 & 7.28 & 9.72 & 74.82 & 159.13 \\
\hline \multicolumn{10}{|c|}{$\mathrm{N}$ levels mean } \\
\hline \multicolumn{2}{|c|}{$60 \mathrm{kgNfed}^{-1}$} & 6.98 & 9.74 & 71.61 & 196.00 & 6.11 & 8.98 & 67.99 & 176.39 \\
\hline \multicolumn{2}{|c|}{$90 \mathrm{kgNfed}^{-1}$} & 8.27 & 10.35 & 79.74 & 157.22 & 7.07 & 9.26 & 76.30 & 137.08 \\
\hline \multicolumn{2}{|c|}{$120 \mathrm{kgNfed}^{-1}$} & 8.84 & 10.32 & 85.54 & 126.11 & 7.91 & 9.42 & 83.84 & 116.14 \\
\hline
\end{tabular}


As for nitrogen fertilization, the results indicate that the irrigation water productivity was increased gradually as nitrogen levels increased, and the highest values e.g. 8.84 and $7.91 \mathrm{kgm}^{-3}$ were recorded with $120 \mathrm{~kg}$ $\mathrm{Nfed}^{-1}$ level in the two seasons of study. The value tended to reduction with 90 and $60 \mathrm{~kg}$ $\mathrm{Nfed}^{-1}$ level to be 6.45 and $21.04 \%$ in $1^{\text {st }}$ season, and to 10.62 and $22.76 \%$ in $2^{\text {nd }}$ season, respectively, lower than IWP under $120 \mathrm{~kg} \mathrm{Nfed}^{-1}$ level. In connection, Kemal (2013) reported that WUE for Shallot plant was gradually increased due to increasing $N$ level.

\section{Nitrogen Use Efficiency (NUE, $\mathbf{k g k g N}^{-1}$ )}

Data in Table 8 indicated that $\mathrm{AFI}_{14}$ regime exhibited higher NUE values, which comprised 177.55 and $159.13 \mathrm{kgkgN}^{-1}$ in 2012/2013 and 2013/2014 seasons, respectively. Values of NUE tended to reduction, under $\mathrm{EFI}$ and $\mathrm{AFI}_{28}$ regimes comparing with $\mathrm{AFI}_{14}$ regime, by 11.31 and $18.72 \%$ in $1^{\text {st }}$ season, and by 11.37 and $18.67 \%$ in $2^{\text {nd }}$ one. These findings still proving that onion crop, was capable to use $\mathrm{N}$ input efficiently under $\mathrm{AFI}_{14}$ regime.

Data revealed that increasing $\mathrm{N}$ level was accompanied with gradual reduction in NUE, where the reduction reached to 24.11 and $39.50 \%$ in $1^{\text {st }}$ season and to 26.66 and $38.14 \%$ in $2^{\text {nd }}$ season under 90 and 120 $\mathrm{kgNfed}^{-1}$ levels, respectively, lower than those with $60 \mathrm{~kg} \mathrm{Nfed}^{-1}$ level.

Interaction of $\mathrm{AFI}_{14}$ regime and $60 \mathrm{~kg}$ $\mathrm{Nfed}^{-1}$ level resulted in the highest NUE values, which comprised 255.33 and 203.00 $\mathrm{kg} \mathrm{kgN}^{-1}$, respectively, in 2012/2013 and 2013/2014 seasons.

\section{Consumptive use efficiency (Ecu,\%):}

In general term, efficiency is a ratio of output to input expressed as percentage. Similarly irrigation efficiency is also expressed as a percentage and is a ratio of irrigation water utilized to the water supplied. The consumptive use efficiency is directly influenced by water placement technique, soil characteristics and plant growth and weather conditions as well. Ecu, \% is referred to the capability of the plants to utilize the water stored in the effective root zone plus that evaporated from the soil surface. Data in Table 8 show that the highest Ecu\% were recorded with $\mathrm{AFI}_{28}$ regime, which reached to 83.18 and $78.96 \%$, comparing with (72.87 and $74.34 \%)$ and (77.50 and $74.82 \%)$, respectively, in $1^{\text {st }}$ and $2^{\text {nd }}$ seasons under $\mathrm{EFI}$ and $\mathrm{AFI}_{14}$ regimes. It is seems that $\mathrm{AFI}_{28}$ regime is superior in this respect, however, $\mathrm{AFI}_{14}$ regime is actually preferable due to both higher onion bulb yield and water use efficiency compared with $\mathrm{AFI}_{28}$ regime.

Data revealed that Ecu\% was gradually improved with increasing $\mathrm{N}$ level, and such trend was true in the two seasons of study. The increase percentages in Ecu\% under $120 \mathrm{kgNfed}^{-1}$ level were 24.08 and $6.66 \%$ in $1^{\text {st }}$ season and 21.10 and $10.43 \%$ in $2^{\text {nd }}$ season, respectively, comparable with 60 and $90 \mathrm{kgNfed}^{-1}$ levels. Such findings are attributable to vigorous growth and higher onion yield, under $120 \mathrm{kgNfed}^{-1}$ level, which in turn the crop consumed more available water that stored in the root zone.

Interaction data illustrated that 120 $\mathrm{kgNfed}^{-1}$ level as interacted with either $\mathrm{AFI}_{28}$ or $\mathrm{AFI}_{14}$ regimes resulted in Ecu\% acceptable figures.

\section{CONCLUSION}

Alternate-furrow irrigation with appropriate irrigation timing e.g. 14 days interval can be used as an efficient method for onion production in semi-arid areas where the production is depended heavily on irrigation. It could be observed that the $\mathrm{AFI}_{14}$ regime is capable to mitigate the water stress, during an irrigation cycle, and to increase onion bulb yield. In addition, it is obviously noticed that the alternate furrow irrigation at 14-days interval and120 kgNfed

${ }^{1}$ is the best combination to achieve higher 
marketable onion bulb yield and to improve irrigation and $\mathrm{N}$ use efficiencies as well.

\section{REFERENCES}

Abdel-Maksoud, H.H., Sanaa A. Othman and A.Y. El-Tawil (2002). Improving water and $\mathrm{N}$-use utilization for field crops via alternate furrow irrigation technique 1Maize crop. Mansoura University Journal of Agricultural Sciences Mansoura University, 27:8761- 8769.

Ali, M.H., M.R. Hoque, A.A. Hassan and A. Khair (2007). Effects of deficit irrigation on yield, water productivity and economic returns of wheat. Agric. Water Manage. 92 (3), 151-161.

Aliyu, U., M.D. Magaji, A. Singh and S.G. Mohammed (2007). Growth and yield of onion (Allium cepa L.) as influenced by Nitrogen and Phosphorus levels. International J. Agric. Res., 2(11): 937944.

AOAC (1975). Official methods of analysis of the association of official agriculture chemists. Twelfth Ed., published by the Association of Official Agriculture Chemists. Washington, D.C.

Awad, Abd El-Halim (2013). Impact of alternate furrow irrigation with different irrigation intervals on yield, water use efficiency, and economic return of corn. Chilean J. of Agric. Res., 73(2):175-180.

Awad, Nemat M., A. A. Abd El-Kader, M. Attia and A. K. Alva (2011). Effects of Nitrogen Fertilization and Soil Inoculation of Sulfur-Oxidizing or Nitrogen-Fixing Bacteria on Onion Plant Growth and Yield. International Journal of Agronomy, Volume 2011, Article ID 316856, 6 pages.

Ayas, S. and C. Demirtas (2009). Deficit irrigation effects on onion (Allium cepa $\mathrm{L}$. E.T. Grano 502) yield in unheated greenhouse condition. Journal of Food, Agriculture and Environment, 7:239-243.

Doornbos, J. and W.O. Pruit (1975). Crop Water Requirements. Irrigation and Drainage Paper, No. 24. FAO, Rome.
El-Beltagy, A.T. and A.F. Abo-Hadeed (2008). The main pillars of the National Program for maximizing the water-use efficiency in the old land. $30 \mathrm{p}$. The Research and Development Council. Ministry of Agriculture and Land Reclamation (MOALR), Giza, Egypt (in Arabic).

El-Sharkawy, A.F., A.Kh. Mostafa and H.H. Abdel Maksoud (2006). Effect of alternate furrow irrigation and transplanting distance on water utilization efficiency for onion crop. Misr Journal of Agricultural Engineering 23:137-150.

Gessesew, W.S., K. Woldetsadik and W. Mohammed (2015). Onion (Allium cepa I. Var. Cepa) Bulb Traits as Affected by Nitrogen Fertilizer Rates and Intra-Row Spacing under Irrigation in Gode, SouthEastern Ethiopia. J Horticulture, 2(4): 3-6.

Hansen, V.W., D.W. Israelsen and D.E. Stringharm (1979). Irrigation Principle and Practices, fourth ed. Johns Willey \&Sons, New York, USA.

Ibrahim, M.A.M. and T.K. Emara (2010). Water saving under alternative furrows surface irrigation in clay soils of north Nile delta. Fourteenth International Water Technology Conference (IWTC), Cairo. 21-23 March. Water Technology Association (WTA), Cairo, Egypt.

Jensen, M.E. (1983). Design and operating of farm irrigation systems. Amer. Soc. Agric. Eng. Michigan, USA, P.827.

Kassam, A. H., D. Molden, E. Fereres and J. Doorenbos (2007). Water productivity: science and practice- introduction. Irrigation Science, 25: 185-188.

Kebede, W. (2003). Shallot (Allium cepa var. ascalonicum) responses to nutrients and soil moisture in sub humid tropical climate. PhD. Thesis, Swedish University of Agricultural Sciences, Agraria P. 367.

Kemal, Y. O. (2013). Effects of irrigation and nitrogen levels on bulb yield, nitrogen uptake and water use efficiency of shallot (Allium cepa var. ascalonicum Baker). African J. Agric. Res, 4637 - 4643 
King, J., A. Gay, R. Sylvester-Bradley, I. Bingham, J. Foulkes, P. Gregory and D. Robinson (2003). Modelling cereal root systems for water and nitrogen capture: towards an economic optimum. Ann. Bot. 91 (3): 383 - 390.

Klute, A. (1986). Methods of Soil Analysis. Part 1, 2nd Ed. ASA and SSSA. Madison, Wisconsin, USA.

Michael, A.M. (1978). Irrigation: Theory and Practices .Vikas Publishing House, Delhi.

Moursy, M.E., H.E. Khalifa, M.M. Attia, M.A. Sayed and A.M. Osman (2007). Effect of organic and nitrogen fertilizers and plant densities on onion production in sandy soil under drip irrigation system. Alex. J. Agric. Res. 52 (1): 103-108.

Okasha, E.M., R.E. Abdelraouf and M.A.A. Abdou (2013). Effect of Land Leveling and Water Applied Methods on Yield and Irrigation Water Use Efficiency of Maize (Zea mays L.) Grown under Clay Soil Conditions. World Applied Sciences Journal 27 (2): 183-190.

Page, A.L., R.H. Miller and D.R. Keeny (1982). Methods of soil analysis. Part II. Chemical and Microbiological properties 2nd ed. Amer. Soc. Agron. Inc. Soil Sci.
Sco. Amer. Inc. Madison, Wisconsin, USA.

Sammis, T.W., M.S. Al-Jammal, S. Ball and D. Smeal (2000). Crop water use of onion. In: Proceedings of sixth International Micro Irrigation Congress, Micro 2000, Cape Town, South Africa, 1 9.

Snedecor, G.V. and W.G. Cochran (1980). Statistical methods, $12^{\text {th }}$ Ed. lowa State Univ. Press, lowa, USA.

Yaso, I.A., H.S. Abdel-Razzak and M.A. Wahb-Allah (2007). Influence of biofertilizer and mineral nitrogen on onion growth, yield and quality under reclaimed calcareous soil condition. J. Agric. Env. Alex. Univ., Egypt, 6 (1): 245-264.

Yaso, I. A. and H. S. Abdel-Razzak (2007). Effect of NPK fertilization on bulb yield and quality of onion under reclaimed calcareous soil conditions. J. Agric. \& Env. Sci. Alex. Uni., Egypt, 6 (1):225 244.

Zhang, J., S. Kang, Z. Liang, Y.Z. Pan, P. Shi, Y.H. Pan, Z.S. Liang and X.T. Hu (2000). Soil water distribution, uniformity and water use efficiency under alternate furrow irrigation in arid areas. Irrigation Sci., 19: 181-190. 


\title{
تأثير الري التبادلي للخطوط تحت مستويات مختلفة من التسميد النيتروجينى علي أداء نباتات البصل تحت ظروف اقليم مصر الوسطي - مصر من من مبرات
}

\author{
محمد محمود عويس ، محمود ابراهيم بلوي
}

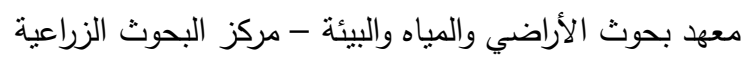

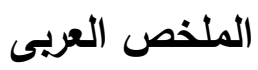

أجريت تجربتان حقليتان خـلال موسمي 2013/2012 ، 2014/2013 بمحطة البحوث الزراعيـة بسدس محافظة بني سويف وذلك لدراسـة تأثثر نظامي الري التبادلي للخطوط (كل 14 ، 28 يوم مقارنـة بالري العادي بالخطوط كل 28 يوم) و ثنلاث مستويات من التسميد النيتروجينى هي60 ، على أداء نباتات البصل والإنتاجية وكفاءات مياة الري و النتروجين وكفاءة الاستهلاك المائي ، وأظهرت النتائج ما بات :يلي

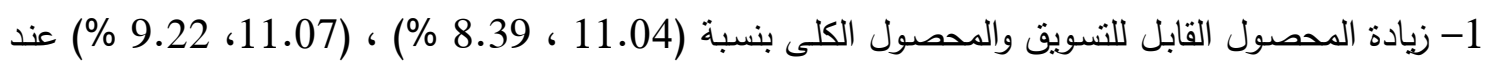

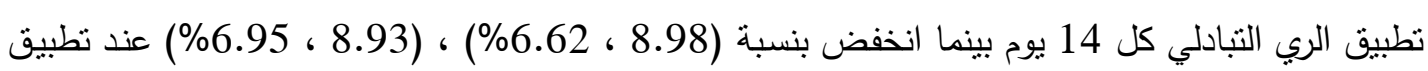
الري التبادلي كل 28 يوم مقارنة بتطبيق الري بالخطوط العادية في كلا من الموسمين على الترتيب. كما أدى ،

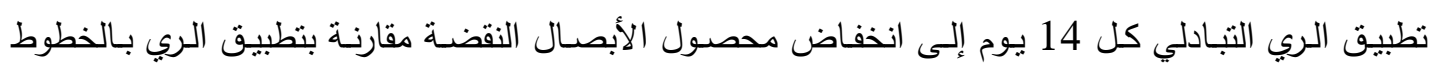
العادية وكذلك الري التبادلي للخطوط كل 28 يوم. أدى الري التبادلي كل 14 يوم إلى تسجيل أعلى القيم لكل التل

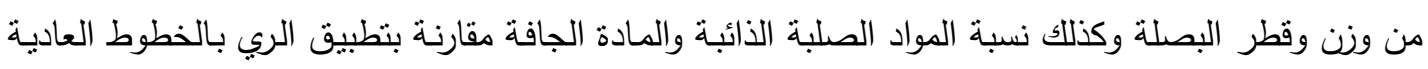
والري التبادلي للخطوط كل 28 يوم خلال موسمي النمو

2- سجلت أعلى قيم للماء المضاف والاستهلاك المائي تحت معاملة الري بالخطوط العادية (ري كل الخطوط)

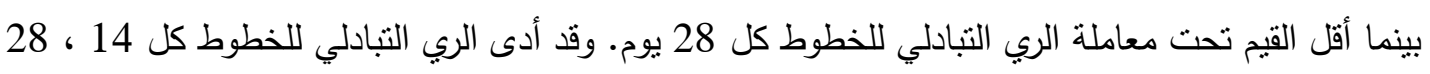

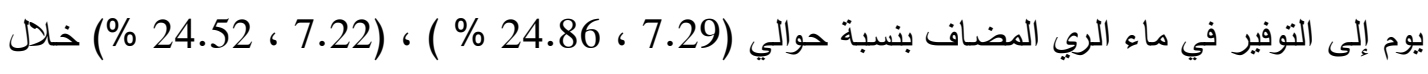
موسمي النمو على ،التزتيب مقارنة بالري بالخطوط التوبر العادية.

3- تطبيق الري التبادلي كل 14 أدي الي تحسين انتاجية مياه الري و كفاءة استخدام المياة و النتروجين بينما بالريا

تحسنت كفاءة الاستهلاك المائي مع الري التبادلي كل 28 يوم مقارنة بمعاملة الري بالخطوط العادية.

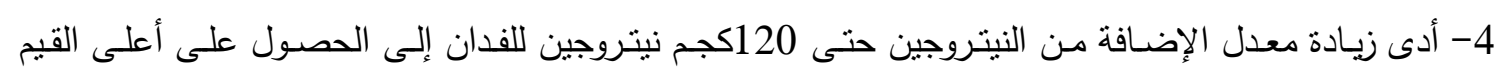
لجميع الصفات تحت الدراسة وكذلك تحسين كفاءات الري خلال موسمي النمو .

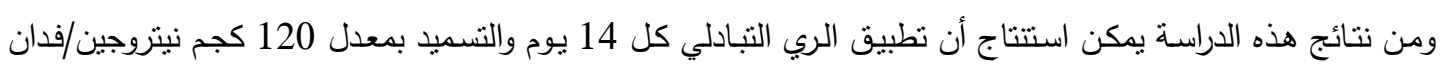

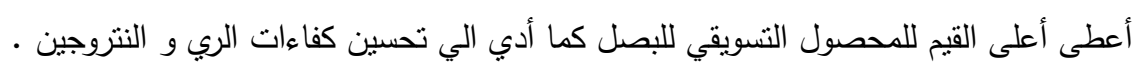

E-mail: Muj-soil@agr.menofia.edu.eg 
Impacts of alternate furrow irrigation and $\mathrm{N}$ - fertilization level on $\ldots \ldots \ldots \ldots \ldots . . . . .$. 